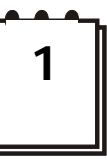

\title{
Bentuk-Bentuk Perubahan Pertukaran dalam Perkawinan Bajapuik
}

\author{
Maihasni $^{1}$, Titik Sumarti ${ }^{2}$, Ekawati Sri Wahyuni ${ }^{2}$, dan Sediono MP.Tjondronegoro ${ }^{2}$
}

\begin{abstract}
ABSTRAK
The objective of this paper to identified and analysis of types that use in bajapuik marriage as a basic of exchange and factors that its influence. The reseach is a qualitative aproach with using multi method approaches in order to explain the phenomena proposed.The result of the study showed that types exchange in bajapuik marriage involved; 1) uang jemputan; 2) uang hilang; 3) uang selo; 4) uang tungkatan. All of types that are exchenged in bajapuik marriage in this moment. In general, the types emerge are caused effect economy and spesific education and inhabitant mobility.
\end{abstract}

Key words: bajapuik marriage, types exchange, effect economy

\section{PENDAHULUAN}

Institusi perkawinan mengemban amanah untuk mensyahkan atau melegalkan perkawinan manusia dalam suatu masyarakat. Hanya saja dalam prakteknya seringkali terdapat berbagai macam aturan atau yang disebut dengan adat, seperti yang terdapat dalam masyarakat Minangkabau. Aturan yang dimaksud berkaitan dengan pertukaran yang terdapat dalam pelaksanaan perkawinan. Melalui pertukaran itu, muncul istilah "lain padang, lain ilalang, lain lubuk, lain pula ikannya. Artinya setiap daerah mempunyai aturan atau adat tertentu sesuai daerahnya masing-masing. Inilah yang terjadi pada perkawinan bajapuik di Pariaman, dan sekaligus membedakan dengan adat perkawinan Minangkabau lainnya. Perbedaan pertukaran itu sekaligus menimbulkan fenomena dalam masyarakat, seperti yang kemukan oleh Azwar, (2001), ada pihak keluarga perempuan menggadaikan dan menjual sawah ladang mereka. Kemudian Utama, (2002), dimana ada kecenderungan perempuan di daerah ini untuk mencari pasangan di luar dari Kabupaten Padang Pariaman, serta Chatra, (2005) semakin meningkatnya jumlah perempuan di daerah ini yang tidak mendapat pasangan. Adanya fenomena-fenomenan ini menimbulkan pandang "negatif" pada perkawinan bajapuik. Meskipun terdapat berbagai fenomena, namun perkawinan bajapuik tetap exis dalam masyarakat. Oleh sebab itu muncul

\footnotetext{
${ }^{1}$ Staf Pengajar Jurusan Sosiologi Fakultas Ilmu Sosial dan Politik Universitas Andalas, Kampus Limau Manis Padang

${ }^{2}$ Staf Pengajar Program Studi Sosiologi Pedesaan Fakultas Ekologi dan Manusia Institut Pertanian Bogor
} 
permasalahan, Apa yang dipertukarkan dalam perkawinan bajapuik? Apa makna dan tujuan dari pertukaran itu?

Berdasarkan permasalahan diatas, maka kajian ini bertujuan untuk mengidentifikasi dan menganalisis bentuk-bentuk perubahan pertukaran yang terdapat dalam perkawinan bajapuik serta faktor-faktor yang mempengaruhinya.

\section{METODOLOGI}

Penelitian ini adalah kajian sosiologi, dengan pendekatan kualitatif. Untuk mendapatkan data yang diperlukan multi metode seperti; studi literatur, wawancara berstruktur dan tidak berstruktur, guna mendapatkan data yang lebih komplit.

Secara paradigmatik, penelitian ini memposisikan diri pada paradigma non posistivistik, khususnya postpositivis. Pilihan paradigma ini dilatar belakangi oleh pertimbangan ontologi, dan epistimologi yang dianut paradigma ini. Secara ontologis paradigma ini bersifat critical realism, menganggap bahwa realitas memang ada dan sesuai dengan kenyataan dan hukum alam tapi mustahil realitas tersebut dapat dilihat secara benar oleh peneliti. Sedangkan secara epistimologis, paradigma postpositivis : Modified dualist/objectivist--hubungan peneliti dengan realitas yang diteliti tidak bisa dipisahkan tapi harus interaktif dengan subjektivitas seminimal mungkin. Dari segi metodologi paradigma postpositivis dapat mewujudkan perpaduan metodologi kuantitatif dan kualitatif, yang menggunakan kaidah-kaidah survey. Perpaduan metodologi tersebut (Guba dan Lincoln (2000; Howe, 2004), dapat berupa penekanan yang lebih kuat pada aspek kuantitatif maupun pada aspek kualitatif, hal ini menurut Creswell (1994) disebut dengan dominant-less atau dominant design. Perpaduan metodologi ini bertujuan untuk mengakumulasi pengetahuan tentang apa saja intervensi yang telah bekerja dalam perkawinan bajapuik. Secara implisit, yang dicari dari suatu intervensi input ialah ditemukan hasilnya (outcome).

\section{TINJAUAN TEORITIS}

Pada dasarnya pertukaran sosial (social exchange) dilandasi oleh prinsip transaksi ekonomi. Walaupun, sebenarnya pertukaran sosial tidak selalu dapat diukur dengan uang, sebab dalam transaksi sosial, juga dipertukarkan hal yang nyata dan tidak nyata. Ini sejalan dengan pandangan Skidmore (1979), bahwa pertukaran (exchange) tidak selalu dimaksudkan untuk menukarkan sesuatu yang nyata, tetapi pertukaran juga meliputi sesuatu yang tidak nyata seperti harga diri atau penghargaan. Selanjutnya pertukaran juga dimaksudkan untuk menghindari sesuatu seperti penderitaan, keadaan yang memalukan lainnya. Untuk itu pertukaran dilakukan dalam rangka untuk mendapatkan keuntungan pada aspek-aspek komparatif dari hubungan kemanusiaan (human relation). ${ }^{3}$

Dari pernyataan Skidmore tersebut, maka jelaslah bahwa gagasan pertukaran (exchange) mempunyai pengertian yang sangat luas dan tidak terbatas pada pemberi dan penerima yang bersifat konkrit. Pandangan yang sama, juga dikemukakan

3 Lebih jauh lihat Skidmore. 1979. "Theoritical Thinking in Sociology". Cambrige University Press. London. Anderson. 1995: 80-98. "Retorical Objectivity in Malinowsky's Argonnaouts", University of Illinois Press. Urbana and Chicago. 
Malinowski bahwa pertukaran tidak hanya dalam bentuk materil tetapi juga dalam bentuk non materil (Turner, (1998); Anderson, (1995).

Adapun assumsinya sebagai berikut:

1. Manusia pada hakikatnya mencari keuntungan yang maksimal—-termasuk keuntungan dari transaksi sosial.

2. Manusia pada hakekatnya mempunyai rasionalitas yang tidak sempurma, tetapi dalam tindakannya secara keseluruhan mengikutsertakan biaya dan keuntungan dalam transaksi sosial.

3. Manusia pada hakikatnya tidak mempunyai informasi yang lengkap untuk semua alternatif-alternatif yang tersedia, tetapi mereka selalu menyadari paling tidak dari beberapa alternatif itu pada dasarnya memperkirakan biaya dan keuntungannya.

4. Manusia selalu bertindak di bawah paksaan, tetapi mereka masih bersaing dengan yang lain dalam mencari keuntungan dalam transaksinya.

5. Manusia selalu mencari keuntungan dalam transaksinya, namun mereka dibatasi oleh sumber-sumber yang mereka miliki dalam hubungan pertukaran.

Dalam perkembangan teori pertukaran sosial (social exchange theory) pertama kali dikembangkan oleh ahli sosiologi George Homans dan kemudian dilanjutkan oleh Peter Blau-menurut Turner (1998) fase pematangan ${ }^{4}$.Tetapi dalam penggunaan teori pertukaran sosial (social exchange theory) dalam studi ilmu sosial banyak ditemukan dalam karya-karya ahli antropologi dan sosiologi. Dalam ilmu Antropologi misalnya, penggunaan teori ini terlihat pada Ekeh (dalam Putra, 2003), di mana Ekeh sendiri membagi teori ini dari dua macam yakni individual dan kolektif. Untuk pertukaran sosial individual dalam Antropologi disebut dengan transaksionalisme dan untuk kolektif disebut dengan strukturalisme.

Homans dalam Turner, (1998), melihat proses pertukaran mengajukan sejumlah preposisi yang erat kaitannya dengan prilaku sosial yang dikaitkan dengan penghargaan (reward) yang terjadi pada kondisi tertentu (Circumstance). Sejumlah preposisi Homans tersebut adalah sebagai berikut:

1. Proposisi sukses (Success Preposition), di mana dalam setiap tindakan tertentu memperoleh ganjaran, maka semakin sering ia akan melakukan tindakan itu.

2. Proposisi stimulus (Stimulus Preposition), jika dimasa lalu terjadi stimulus yang khusus atau seperangkat stimuli, merupakan peristiwa di mana

\footnotetext{
${ }^{4}$ Dalam perkembangannya dianggap sebagai periode awal dari teori pertukaran (Exhange Theory) adalah pemikiran yang dikemukakan Simmel dalam karyanya "the Philosophy of Money" yang merupakan kritikan terhadap tulisan Marx yang berjudul "Value Theory of Labor", namun ini dikatakan sebagai awal pemikiran dari teori pertukaran social (social exchange). Simmel mengemukakan sejumlah proposisi yang kemudian dikenal dengan prinsip-prinsip pertukaran Simmel (Simmel's Exchange Principles). Lihat Turner, 1998.
} 
tindakan seseorang memperoleh ganjaran, maka semakin memungkinkan seseorang melakukan tindak serupa.

3. Proposisi nilai (Value Preposition), di mana semakin tinggi nilai suatu tindakan, maka semakin sering seseorang melakukan tindakan itu.

4. Proposisi kejenuhan (Satiation Preposition), di mana semakin sering dimasa lalu seseorang menerima suatu ganjaran, maka semakin kurang bernilai bagi orang tersebut peningkatan setiap unit ganjaran itu.

5. Proposisi persetujuan (Approval Preposition), bila tindakan seseorang tidak memperoleh ganjaran yang diharapkan atau menerima hukuman yang tidak diinginkan, maka dia akan marah; dia menjadi cenderung menunjukan prilaku agresif dan hasil prilaku demikian menjadi lebih bernilai baginya (Poloma, 2000; Ritzer, 1985; Turner, 1998).

6. Proposisi rasionalitas (Rationality Preposition), dalam memilih antara tindakan alternatif, seseorang akan memilih sesuatu itu seperti dirasakannya ketika nilai dari hasil dikalikan dengan kemungkinan hasil tersebut adalah lebih besar (Turner, 1998).

Dari keenam proposisi yang diajukankan, Homans menekankan pada proposisi ketiga dari exchange theory-nya. Lebih jauh dikatakan bahwa makin bernilai bagi seseorang tingkahlaku orang lain yang ditujukan kepadanya, makin besar kemungkinan atau makin sering ia akan mengulangi tingkahlakunya dan akhirnya pertukaran kembali akan terjadi. Namun reward yang diberikan terhadap orang lain adalah yang mempunyai nilai yang lebih rendah menurut penilain aktor, tetapi mempunyai nilai lebih bagi orang yang diberi.

Pertukaran (exchange) tidak akan terjadi kalau nilai sesuatu yang ditukarkan itu sama, karena itu exchange hanya terjadi bila cost yang diberikan akan menghasilkan benefit yang lebih besar dan kedua belah pihak sama-sama mendapat untung, dan keuntungan itu mengandung unsur psikilogis (Turner, 1998; Ritzer, 1985). Artinya pertukaran di sini termasuk pada pertukaran yang melebihi pertimbangan ekonomi.

Blau dalam hal ini juga menerima preposisi yang diajukan Homans. Untuk itu Blau mengatakan bahwa prilaku (behavioristic) merupakan dasar dari proses sosial dan kebutuhan untuk saling tukar dan untuk mendapatkan keuntungan dalam suatu kerangka yang tetap merupakan suatu mekanisme awal dari interaksi sosial (Turner, 1998).

Dalam rangka untuk memperkuat pernyataannya, Blau mengajukan sejumlah proposisi yang pada akhirnya dikenal dengan Blau's Implicit Exchange Principle's adalah sebagai berikut:

1. Prinsip Rasionalitas (Rationality Principle), semangkin orang mengharapkan keuntungan pada orang lain, maka semangkin orang itu semakin luas aktivitasnya.

2. Prinsip Timbal balik ( Reciprocity principle), semakin besar reward yang diterima sesorang dari pertukaran dengan orang lain, maka kemungkinan pertukaran akan sering muncul dan diikuti oleh pertukaran berikutnya. Jika 
hubungan timbal balik itu dilanggar dalam hubungan pertukaran, kelompok yang dirugikan akan memberi sanksi kepada pelanggar norma tersebut.

3. Prinsip-prinsip Keadilan (Justice Principles), semakin stabil hubungan pertukaran, maka semakin mungkin hubungan pertukaran di atur oleh norma-norma. Semakin sedikit norma-norma yang direalisasikan pada suatu pertukaran, maka menempati sipelaku pada sanksi yang negatif dari orangorang yang merasa dirugikan.

4. Prinsip Kegunaan Marginal (Marginal Utility Principle), semakin besar reward yang diterima, semakin sering suatu aktivitas dilakukan. Sebaliknya semakin sedikit nilai suatu aktivitas, semakin sedikit aktivitas itu dilakukan.

5. Prinsip-prinsip Ketidak seimbangan (Imbalance Principles), semakin stabil dan dan seimbang suatu pertukaran di antara unit-unit sosial, semakin pertukaran lainnya menjadi tidak seimbang.

Dengan merujuk pada proposisi yang diajukan Homans dan Blau, maka jelaslah bahwa keduanya merujuk pada aras yang berbeda. Walaupun demikian, proposisi Blau merupakan perluasan/pengembangan dari proposisi Homans. Dengan katalain Homans memulai teorinya dari ilmu ekonomi dan bukan prinsip-prinsip psikologi yang pada sosiologi termasuk pada aras mikroskopik, sedangkan Blau mencoba menyatukan pandangan paradigma fakta sosial dengan paradigma prilaku sosial pada aras makroskopik (Turner, 1998). Dengan memulai teorinya dari ilmu ekonomi, maka Homans bertumpu pada assumsi bahwa orang terlibat dalam prilaku untuk memperoleh ganjaran atau menghindari hukuman baik ekstrinsik maupun intrinsik. Bahkan lebih jauh Homans melihat semua perilaku sosial tidak hanya perilaku ekonomi sebagai hasil pertukaran yang demikian, tetapi juga prilaku sosial lainnya (Poloma, 2000).

Mengacu pada persoalan perkawinan bajapuik, aktor mau melakukannya didasarkan pada assumsi untuk mendapat keuntungan yang maksimal. Artinya dengan memberikan sejumlah uang untuk mendapatkan keuntungan yang lebih besar, yakni mendapatkan menantu atau suami bagi anak perempuannya. Oleh sebab itu dorongan untuk melakukan pertukaran didasarkan pada proposisi nilai.

\section{HASIL DAN PEMBAHASAN}

Berdasarkan hasil penelitian lapangan menunjukan bahwa saat ini terdapat bermacam bentuk-bentuk uang dalam perkawinan bajapuik. Adapun bentuk-bentuk uang tersebut dalam parakteknya kadang-kadang tidak berlaku seutuhnya, tergantung pada kesepakatan keluarga kedua belah pihak. Meskipun demikian, berikut diuraikan bentuk-bentuk pertukaran itu, sekaligus dengan makna yang terkandung dari masing-masing uang tersebut, yang pada akhirnya berimplementasi pada exisnya perkawinan bajapuik dalam masyarakat.

\section{UANG JEMPUTAN}

\section{Konsep Uang Jemputan}

Secara konseptual uang jemputan adalah uang yang diberikan oleh pihak perempuan kepada pihak laki-laki sebagai persyaratan dalam perkawinan dan dikembalikan lagi 
pada pihak perempuan pada saat mengunjungi mertua untuk pertama kalinya. Uang jemputan ini bewujud benda yang bernilai ekonomis, seperti emas dan benda lainnya.

Uang jemputan yang berwujud emas, pada awalnya berupa rupiah dan ringgit emas ${ }^{5}$, kemudian berkembang menjadi cincin, kalung dan gelang emas. Perubahan ini terjadi karena bentuknya sudah ketinggalan zaman, sehingga tidak diminati oleh sipembeli sebagai persyaratan dalam perkawinan bajapuik. Atas dasar itu, pedagang emas tidak lagi menjual atau memproduksi bentuk emas yang demikian.

Jumlah uang jemputan berbentuk emas ini bervariasi, mulai 2 hingga 20 emas, tergantung kepada kesepakatan dan kemampuan dari pihak perempuan. Uang jemputan dalam bentuk emas dapat digunakan sebagai perhiasan bagi mempelai perempuan (anak daro). Selain itu dapat pula menjadi modal bagi kedua mempelai dalam menjalan rumahtangga nantinya.

Seiring dengan perkembangan zaman, ternyata memberi inspirasi pula pada wujud uang jemputan ini. Selain uang jemputan dalam bentuk emas masih berlaku hingga saat ini, wujud lain dari uang jemputan terdapat pula dalam perkawinan bajapuik yakni berupa kendaraan roda dua ataupun roda empat, hingga sebuah rumah. Adanya benda lain ini dalam perkawinan bajapuik sekaligus menunjukan prestise dari calon mempelai laki-laki dan orang yang datang (pihak perempuan) tidak sembarangan. Keluarga pihak perempuan dalam hal ini berarti berasal dari orang yang mempunyai prestise pula.

Uang jemputan berbentuk benda lain ini, pada umumnya di gunakan oleh kedua mempelai sebagai modal untuk mengarungi rumah tangga nantinya. Tetapi ada pula uang jemputan yang diperuntukan dan digunakan oleh orang tua mempelai laki-laki, tergantung pada permintaan dan kerelaan kedua belah pihak. Perutukkan kepada orang tua mempelai laki-laki dimaksudkan sebagai perhatian atau simpati pihak perempuan atas ketidakmampuannya secara ekonomi. Disinilah letak perbedaan antara uang jemputan yang berwujud emas dengan wujud uang jemputan dalam bentuk yang lain. Uang jemputan yang berwujud emas akan kembali lagi kepada pihak perempuan melalui mempelai perempuan (anak daro) sebagai pemberian atau paragiah jalang dari mertua. Sedangkan uang jemputan yang berupa kendaraan fokusnya kepada calon mempelai laki-laki sendiri (marapulai) dan dapat digunakan langsung oleh calon mempelai laki-laki (marapulai).

Uang jemputan pada sebagian masyarakat khususnya yang berada di daerah perkotaan, maknanya sama dengan uang hilang, sehingga uang jemputan disini berupa uang. Uang jemputan dalam makna yang sebenarnya jarang/tidak dipakai lagi dalam perkawinan bajapuik. Alasannya agar lebih sederhana dan tidak merepotkan pihak perempuan. Sebagai gambaran dari fenomena tersebut dapat dilihat pada tabel 1 berikut ini.

\footnotetext{
${ }^{5} 1$ rupiah emas berjumlahnya 16,6 gram atau lebih kurang 6,5 emas. Kemudian 1 ringgit emas berjumlah 33 gram atau lebih kurang 13 emas.
} 
Tabel. 1 Wujud Uang Jemputan

\begin{tabular}{|c|c|c|c|c|c|c|c|}
\hline \multirow[b]{2}{*}{ Kategori } & \multicolumn{2}{|c|}{ Generasi Muda } & \multicolumn{2}{|c|}{ PeLaku } & \multicolumn{2}{|c|}{ Orang Tua } & \multirow[b]{2}{*}{ Total } \\
\hline & $\begin{array}{c}\text { Laki- } \\
\text { laki }\end{array}$ & Perempuan & $\begin{array}{l}\text { Laki- } \\
\text { laki }\end{array}$ & Perempuan & $\begin{array}{c}\text { Laki- } \\
\text { laki }\end{array}$ & Perempuan & \\
\hline Uang & $\begin{array}{c}22 \\
(36,7)\end{array}$ & $\begin{array}{c}18 \\
(30,0)\end{array}$ & $\begin{array}{c}15 \\
25,0\end{array}$ & $\begin{array}{c}17 \\
(28,3)\end{array}$ & $\begin{array}{c}8 \\
(13,3)\end{array}$ & $\begin{array}{c}6 \\
(10,0)\end{array}$ & $\begin{array}{c}86 \\
(23,9)\end{array}$ \\
\hline Emas & $\begin{array}{c}26 \\
(43,3)\end{array}$ & $\begin{array}{c}29 \\
(48,3)\end{array}$ & $\begin{array}{c}38 \\
(63,3)\end{array}$ & $\begin{array}{c}40 \\
(66,7)\end{array}$ & $\begin{array}{c}43 \\
(71,7)\end{array}$ & $\begin{array}{c}44 \\
(73,3)\end{array}$ & $\begin{array}{c}220 \\
(61,1)\end{array}$ \\
\hline $\begin{array}{l}\text { Benda } \\
\text { Lainnya }\end{array}$ & $\begin{array}{c}12 \\
(20,0)\end{array}$ & $\begin{array}{c}13 \\
(21,7)\end{array}$ & $\begin{array}{c}7 \\
(11,7)\end{array}$ & $\begin{array}{c}3 \\
(5,0)\end{array}$ & $\begin{array}{c}9 \\
(15,0)\end{array}$ & $\begin{array}{c}10 \\
(16,7)\end{array}$ & $\begin{array}{c}54 \\
(15,0)\end{array}$ \\
\hline Total & $\begin{array}{c}60 \\
(100)\end{array}$ & $\begin{array}{c}60 \\
(100)\end{array}$ & $\begin{array}{c}60 \\
(100)\end{array}$ & $\begin{array}{c}60 \\
(100)\end{array}$ & $\begin{array}{c}60 \\
(100)\end{array}$ & $\begin{array}{c}60 \\
(100)\end{array}$ & $\begin{array}{c}360 \\
(100)\end{array}$ \\
\hline
\end{tabular}

Tabel di atas menunjukan bahwa sebagian besar atau sebanyak 76,1 persen dari total responden mengatakan wujud uang jemputan yang berlaku saat ini berupa benda yang bernilai ekonomis yakni berupa emas dan benda lainnya. Kemudian 23,9 persen yang mengatakan wujud uang jemputan berupa uang. Pada umumnya mereka berasal generasi muda dan generasi sedang (pelaku) yang jumlahnya mencapai 20,0 persen dan bermukim daerah perkotaan. Sacara spesifik antara jenis kelamin tidak terdapat perbedaan yang signifikan yakni 10,3 dan 9,7 persen mengenai wujud uang pada uang jemputan.

\section{Tujuan dan Makna Uang Jemputan}

Uang jemputan sebagai persyaratan adat dalam perkawinan, bertujuan untuk menjemput laki-laki yang hendak dijadikan menantu. Sebagai persyaratan adat, uang jemputan merupakan simbolisasi dari seseorang yang berasal dari keturunan atau asal-usul yang jelas dan sebagai penghormatan kepadanya diberi uang jemputan. Inilah makna uang jemputan pada awalnya.

Kemudian dalam prakteknya saat ini, makna uang jemputan sebagai pemberian orang tua kepada anak dan menantunya. Sebagai pemberian orang tua kepada anak perempuannya, wujud uang jemputan biasanya dalam bentuk emas. Sementara itu sebagai pemberian mertua kepada menantu, wujud uang jemputan berbentuk benda lain (kendaraan). Uang i-laki sebagai menantu. Sedangkan sebagai penghomatan atau penghargaan kepada seorang laki-laki yang diterima sebagai menantu terletak pada uang hilang atau uang dapur. Penghargaan yang lebih besar, akan terlihat pada jumlah uang hilang yang semangkin besar dan sekaligus mengindikasikan bahwa seseorang laki-laki mempunyai kedudukan yang tinggi dalam masyarakat.

Meskipun, ada istilah pemberian orang tua kepada anaknya dan pemberian mertua kepada menantunya, keduanya itu bertujuan untuk kebahagian dari anak dan menantu. Emas ataupun benda lainnya yang diberikan sebagai uang jemputan adalah hak milik dari kedua pengantin dan dapat digunakan sebagai modal dalam menjalan hidup berumahtangga nantinya. Barang-barang itu dapat digunakan secara bersamasama dan untuk kepentingan bersama dalam keluarga baru itu.

Dengan uang jemputan jemputan yang berwujud benda (kendaraan) ini ditujukan kepada calon pengantin lakyang berupa emas, kendaraan roda dua dan empat dalam 
perkawinan bajapuik saat ini, selain sebagai persyaratan adat, juga menunjukan status dari orang yang dijemput ${ }^{6}$. Artinya semakin besar jumlah uang jemputan, mengindikasikan laki-laki yang dijemput mempunyai kedudukan atau prestise yang tinggi pula dalam masyarakat. Begitu juga sebaliknya, di mana keluarga pihak perempuan yang mampu memberi uang jemputan yang tinggi berarti berasal dari orang yang mampu pula. Sehingga keduanya mempunyai titik temu dalam pelaksanaan perkawinan bajapuik. Dengan memakai terminilogi dari Homan dalam Turner (1998:266); Ritzer dan Goodmann ( 2004:364), tindakan seperti ini, dikenal dengan tindakan yang bernilai (value behavior). Gejala ini menciptakan melanggengkan uang jemputan dalam perkawinan bajapuik.

\section{Waktu Penentuan dan Pemberian Uang Jemputan}

Penentuan jumlah uang jemputan dibicarakan pada saat tata cara meresek. Kemudian pada saat pertunangan, uang jemputan ditetapkan secara resmi. Penentuan uang jemputan berasal dari pihak laki-laki dan untuk pemberian dilakukan oleh pihak perempuan. Meskipun kedua belah pihak menempati posisi berseberangan, namun untuk penentuan jumlah uang jemputan itu, keluarga kedua belah pihak bertemu dan mengadakan perundingan. Setelah didapat suatu kesepakatan, maka pada waktu yang yang ditentukan uang jemputan diberikan kepada pihak laki-laki.

Aktor yang terlibat dalam penentuan uang jemputan antara lain; ibu, ayah, mamak dan seorang ninik mamak dari keluarga kedua belah pihak. Melalui aktor-aktor ini, uang jemputan ditetapkan jumlahnya. Bagi pihak perempuan berapapun jumlah uang jemputan yang di minta oleh pihak laki-laki pada umumnya tidak ditawar dan biasanya langsung di terima saja. Ini terjadi, jika uang jemputan dipahami sebagai uang jemputan, yang akan kembali lagi kepada pihak perempuan, seperti yang terjadi pada masyarakat yang masih memegang teguh nilai-nilai atau norma-norma adat perkawinan bajapuik. Berbeda halnya dengan uang jemputan yang dipahami sebagai uang hilang seperti yang terjadi pada sebagian masyarakat. Penawaran terhadap uang jemputan akan lebih besar terjadi. Sehingga kedua belah pihak antara orang tua laki-laki dan orang tua perempuan akan mengadakan musyawarah untuk mendapatkan kata mufakat.

Orang tua dalam hal ini mempunyai peran penting dalam menentukan uang jemputan ini. Apalagi, bila pada suatu keluarga luas itu banyak anggota keluarganya yang tidak menetap di daerah asalnya, keikut sertaannya sudah dapat dipastikan sangat terbatas. Tempat tinggal yang jauh, serta pekerjaaan yang tidak dapat ditinggalkan adalah menjadi alasan utamanya. Tetapi tanpa mengabaikan perannnya pada kemenakan, seorang mamak yang berada dirantau dapat saja memberi usulan kepada saudara perempuan mengenai jumlah uang jemputan. Meskipun pada akhirnya uang jemputan itu dapat di putuskan sendiri oleh orang tua tanpa kehadiranya. Kondisi seperti ini sudah lazim berlaku dalam perkawinan bajapuik, kalaupun ada mamak yang ikut menentukan mengenai uang jemputan, berarti mamak tersebut berdomisili di daerah itu. Itulah pulalah sebabnya peranan mamak dalam penentuan uang jemputan ini sangat terbatas.

\footnotetext{
${ }^{6}$ Laki-laki yang diterima sebagai menantu, apakah berasal dari golongan biasa atau golongan yang mempunyai status dalam masyarakat.
} 
Setelah semua disepakati, uang jemputan biasanya diberikan pada saat mempelai laki-laki dijemput untuk melangsung pernikahan. Pemberian uang jemputan dilakukan di rumah pihak keluarga laki-laki. Pada saat itu, pihak perempuan datang secara berombongan ke rumah pihak keluarga laki-laki. Mereka terdiri dari anggota keluarga terdekat dari anak daro, seperti, mamak, kakak, mande ${ }^{7}$, isteri dari mamak (orang sumando) dan ninik mamak. Kemudian uang jemputan diberikan oleh salah seorang yang mewakili keluarga pihak perempuan atau yang biasa disebut dengan ninik mamak. Sedangkan dari pihak laki-laki, uang jemputan diterima pula oleh ninik mamak dan disaksikan oleh anggota keluarganya pula. Bersamaan dengan pemberian uang jemputan diserahkan pula persyaratan adat lainnya seperti uang hilang dan kampia sirih. Pemberian uang jemputan itu dalam perkawinan bajapuik, pada umumnya dilakukan pada saat akad nikah, seperti yang terlihat pada tabel 2 berikut ini.

Tabel 2. Waktu Uang Jemputan diberikan

\begin{tabular}{|l|c|c|c|c|c|c|c|}
\hline \multirow{3}{*}{ Kategori } & \multicolumn{2}{|c|}{ Generasi Muda } & \multicolumn{2}{|c|}{ PeLaku } & \multicolumn{2}{c|}{ Orang Tua } & \multirow{2}{*}{ Total } \\
\cline { 2 - 7 } & $\begin{array}{c}\text { Laki- } \\
\text { laki }\end{array}$ & Perempuan & $\begin{array}{c}\text { Laki- } \\
\text { laki }\end{array}$ & Perempuan & $\begin{array}{c}\text { Laki- } \\
\text { laki }\end{array}$ & Perempuan & \\
\hline 1-6 bulan & 2 & 6 & 2 & 7 & 0 & 2 & 19 \\
& $(3,3)$ & $(10)$ & $(3,3)$ & $(11,7)$ & $(0)$ & $(3,3)$ & $(5,3)$ \\
\hline Saat Akad & 58 & 54 & 58 & 53 & 60 & 58 & 341 \\
Nikah & $(96,7)$ & $(90)$ & $(96,7)$ & $(88,3)$ & $(100)$ & $(96,7)$ & $(94,7)$ \\
\hline Sesudah & 0 & 0 & 0 & 0 & 0 & 0 & 0 \\
Pesta & $(0)$ & $(0)$ & $(0)$ & $(0)$ & $(0)$ & $(0)$ & $(0)$ \\
\hline Total & 60 & 60 & 60 & 60 & 60 & 60 & 360 \\
& $(100)$ & $(100)$ & $(100)$ & $(100)$ & $(100)$ & $(100)$ & $(100)$ \\
\hline
\end{tabular}

Tabel di atas menunjukan, bahwa pada umumnya uang jemputan diberikan pada saat akad nikah yang jumlahnya 94,7 persen. Pemberian uang jemputan sebelum akad nikah jumlahnya relatif kecil yakni 5,3 persen. Adanya pemberian uang jemputan sebelum akad nikah, disebabkan oleh pemaknaan yang sama terhadap konsep uang jemputan dan uang hilang. Ini terjadi oleh kebiasaan dari masyarakat setempat (kota) yang tidak lagi memakai uang jemputan dalam arti yang sebenarnya. Konsep uang jemputan yang diidentikan dengan uang hilang menyebabkan pemaknaan responden untuk pemberian uang jemputan pada pelaksanaan perkawinan bajapuik seperti yang terlihat pada tabel di atas. Secara lebih spesifik 1,1 persen pandangan yang sama itu berasal dari laki-laki dan 3,6 persen dari perempuan. Dari perbandingan itu, dapat dikatakan laki-laki lebih memahami tentang perkawinan bajapuik jika dibandingkan perempuan.

\section{Sejarah Munculnya Uang Jemputan}

Munculnya uang jemputan dalam perkawinan bajapuik diperoleh dua versi yakni; berkaitan dengan orang asa dan sistem keturunan matrilineal yang dianut oleh orang Minangkabau pada umumnya dan Pariaman khususnya. Pertama, orang asa yang dimaksudkan disini adalah orang yang pertama menempati (manaruko) suatu daerah di Minangkabau. Di dalam falsafah adat Minangkabau disebutkan, "darek berpenghulu, rantau ba rajo”. Secara eksplisit falsafah ini menggambarkan, bahwa

\footnotetext{
${ }^{7}$ Saudara perempuan dari ibu, yang dilihat dari sisi mempelai perempuan (anak daro).
} 
orang Minangkabau mendiami dua kawasan yang berbeda yakni darek dan rantau. Sebagai sebutan untuk orang yang mendiami daerah darek adalah penghulu yang berarti pemimpin ${ }^{8}$. Sedangkan untuk daerah rantau, sebutan untuk pemimpinnya adalah rajo (raja). Kedua sebutan yang akan diwarisi kepada keturunannya dan mengisyaratkan orang asa di Minangkabau.

Orang asa di dalam struktur orang Minangkabau menempati posisi diatas, jika dibandingkan dengan orang datang. Berkaitan dengan perkawinan di Minangkabau, orang asa inilah yang diutamakan diterima sebagai menantu, karena dipahami oleh masyarakat sebagai orang yang mempunyai asal-usul yang jelas. Sebagai penghargaan kepada orang asa ini, di dalam perkawinan di Minangkabau diberi uang jemputan.

Kedua, sebagai implimentasi dari sistem matrilineal. Sistem matrilineal yang dianut oleh orang Minangkabau di dasari oleh orang Minangkabau yang berguru ke alam, yang pada akhirnya melahirkan falsafah, "Alam Takambang Jadi Guru”. Dalam berguru kepada alam, orang minangkabau melihat seluruh makhluk yang mempunyai anak mempunyai kedekatan kepada ibunya. Selanjutnya dalam sistem matrlineal ini, harta pusaka, baik rendah dan maupun tinggi menjadi hak milik dari kaum perempuan. Kaum perempuanlah yang memetik hasil dari harta tersebut, sedangkan kaum laki-laki tidak mendapatkan apa-apa dari harta tersebut. Oleh sebab itu, maka wajarlah laki-laki yang diterima sebagai menantu diberi uang jemputan sebagai modal bagi mereka untuk hidup berumahtangga.

\section{UANG HILANG}

\section{Konsep Uang Hilang}

Uang hilang adalah uang yang diberikan oleh pihak perempuan kepada pihak lakilaki sebagai persyaratan dalam perkawinan dan dapat dipergunakan sepenuhnya oleh pihak laki-laki, terutama orang tua. Uang hilang berwujud benda, khususnya berupa uang. Sebagai gambaran dapat dilihat pada tabel 3 berikut ini.

Tabel 3. Wujud Uang Hilang

\begin{tabular}{|l|c|c|c|c|c|c|c|}
\hline \multirow{3}{*}{ Kategori } & \multicolumn{2}{|c|}{ Generasi Muda } & \multicolumn{2}{|c|}{ PeLaku } & \multicolumn{2}{c|}{ Orang Tua } & \multirow{2}{*}{ Total } \\
\cline { 2 - 7 } & $\begin{array}{c}\text { Laki- } \\
\text { laki }\end{array}$ & Perempuan & $\begin{array}{c}\text { Laki- } \\
\text { laki }\end{array}$ & Perempuan & $\begin{array}{c}\text { Laki- } \\
\text { laki }\end{array}$ & Perempuan & \\
\hline Uang & 55 & 48 & 57 & 53 & 59 & 58 & 330 \\
& $(91,7)$ & $(80,0)$ & $(95,0)$ & $(88,3)$ & $(98,3)$ & $(96,7)$ & $(91,7)$ \\
\hline Emas & 1 & 6 & 0 & 2 & 1 & 2 & 12 \\
& $(1,7)$ & $(10,0)$ & $(0)$ & $(3.4)$ & $(1,7)$ & $(3,3)$ & $(3,3)$ \\
\hline Benda & 4 & 6 & 3 & 5 & 0 & 0 & 18 \\
Lainnya & $(6.6)$ & $(10,0)$ & $(5,0)$ & $(8,3)$ & $(0)$ & $(0)$ & $(5,0)$ \\
\hline Total & 60 & 60 & 60 & 60 & 60 & 60 & 360 \\
& $(100)$ & $(100)$ & $(100)$ & $(100)$ & $(100)$ & $(100)$ & $(100)$ \\
\hline
\end{tabular}

Dari tabel di atas menunjukan bahwa sebagian besar (91,7 persen) wujud uang hilang berupa uang. Kemudian ada sekitar 8,3 persen, wujud uang hilang berupa emas dan benda lainnya. Adanya anggapan mengenai wujud uang hilang berupa

\footnotetext{
${ }^{8}$ Seseorang diangkat sebagai pemimpin, berarti orang yang menempati atau menguasai daerah itu pertama kalinya.
} 
emas atau benda lain disebabkan oleh pemahaman yang sama antara uang hilang dengan uang jemputan. Anggapan itu pada umumnya berasal dari generasi muda dan generasi sedang (pelaku), yang berasal dari daerah perkotaan. Kemudian secara spesifik 2,2 persen dari laki-laki dan 5,5 persen dari perempuan. Dengan demikian tingkat pemahaman nilai adat perkawinan bajapuik pada jenis kelamin laki-laki lebih tinggi di bandingkan dengan jenis kelamin perempuan.

Nama lain dari uang hilang adalah uang dapur. Uang dapur dimaksukan adalah untuk membeli kebutuhan dapur. Atas dasar itu wujud uang hilang berupa uang seperti yang terlihat pada tabel 3 di atas. Kebutuhan dapur yang dimaksud adalah mempersiapkan makanan yang akan dihidangkan ketika mempelai perempuan datang ke rumah mempelai laki-laki untuk bertamu secara adat atau yang biasa disebut dengan acara menjalang. Namun untuk saat ini, uang hilang juga digunakan untuk mempestakan mempelai laki-laki di rumah orang tuanya. Jika dahulu hanya pihak perempuan yang mengadakan pesta, namun sekarang kedua belah pihak mengadakan pesta. Dengan demikian uang hilang digunakan untuk kebutuhan dapur untuk undangan dari pihak laki-laki dan kebutuhan dapur untuk mempelai perempuan (anak daro) untuk penyambutan acara menjalang. Untuk saat ini kegunaan uang hilang, ada kecendrungan untuk pesta pihak laki-laki yang lebih diutama. Kegunaan lain uang hilang dalam perkawinan bajapuik adalah untuk menambah uang jemputan (untuk paragiah jalang), membeli kebutuhan mempelai laki-laki, seperti baju, sepatu dan sebagainya serta dapat pula sebagai modal bagi mempelai dalam berumahtangga.

Adanya berbagai macam kegunaan dari uang hilang diatas menunjukan, konsep uang hilang dalam perkawinan bajapuik, tidak benar-benar hilang. Tetapi terdapat pendistribusian uang tersebut pada pos-pos lain, seperti yang disebutkan diatas dalam perkawinan bajapuik. Meskipun demikian, pada kasus-kasus tertentu, kemungkinan uang hilang benar-benar hilang tetap ada. Fenomena itu merupakan kasuistik saja dan tidak dapat digeneralisasi sebagai karakteristik dari perkawinan bajapuik. Kasus ini terutama terjadi pada keluarga-keluarga yang tidak memahami nilai-nilai yang terkandung dalam perkawinan bajapuik.

\section{Tujuan dan Makna Uang Hilang}

Sebagaimana telah disinggung sebelumnya, dimana uang hilang adalah sebagai persyaratan dalam perkawinan bajapuik. Ini berarti bahwa uang hilang menjadi hal yang penting dalam perkawinan bajapuik. Jika uang hilang tidak dipenuhi maka perkawinan dapat dipastikan tidak terlaksana. Dengan demikian tujuan uang hilang dalam perkawinan bajapuik adalah untuk menjemput mempelai laki-laki (marapulai), agar perkawinan dapat terlaksana.

Sementara itu makna yang terkandung dari uang hilang sebagai bentuk penghargaan pada sebuah status atau kedudukan dari seorang laki-laki yang diterima sebagai menantu? . Sebagai bentuk penghargaan tersebut diberi uang hilang. Uang hilang

\footnotetext{
${ }^{9}$ Pada awal perkawinan bajapuik penghargaan itu terletak pada status gelar keturunan yang di warisi dari ayah. Sebagai wujud penghargaan tersebut disimbolkan oleh uang jemputan. Semangkin tinggi atau besar jumlah uang jemputan, menunjukan seseorang calon pengantin laki-laki mempunyai prestise atau kedudukan yang baik di tengan masyarakat.
} 
yang semangkin tinggi menunjukan, status atau kedudukan seorang laki-laki yang tinggi pula di mata masyarakat, dan begitu juga sebaliknya.

\section{Waktu Penentuan dan Pemberian Uang Hilang}

Penentuan jumlah uang hilang secara resmi, ditetapkan pada saat pertunangan (tukar cincin). Penentuan ini bersamaan dengan penetapan uang jemputan. Jauh sebelum penetapan ini, kedua belah pihak terutama orang tua bertemu dan membicarakan mengenai jumlah uang jemputan dan uang hilang ini. Tepatnya pada saat merasek atau merasok. Pembicaraan itu dapat terjadi 2 sampai 3 kali pertemuan, apabila belum didapat kesepakatan antara kedua belah pihak. Pada kesempatan yang sama, juga dibicarakan persyaratan lain yang harus dipenuhi oleh pihak perempuan untuk pelaksanaan perkawinan nantinya. Ketika tahap berikutnya yang harus dilalui dalam perkawinan bajapuik, penentuan itu hanya sebagai formalitas saja.

Untuk penentuan uang hilang, aktor yang terlibat dari pihak laki-laki pada umumnya adalah orang tua, mamak. Kecendrungan yang terjadi saat ini, adanya keterlibatan dari calon mempelai laki-laki dalam penentuan uang hilang, seperti yang terlihat pada tabel 4 berikut ini.

Tabel 4. Penentuan Uang Hilang

\begin{tabular}{|l|c|c|c|c|c|c|c|}
\hline \multirow{3}{*}{ Kategori } & \multicolumn{2}{|c|}{ Generasi Muda } & \multicolumn{2}{c|}{ PeLaku } & \multicolumn{2}{c|}{ Orang Tua } & \multirow{2}{*}{ Total } \\
\cline { 2 - 7 } & $\begin{array}{c}\text { Laki- } \\
\text { laki }\end{array}$ & Perempuan & $\begin{array}{c}\text { Laki- } \\
\text { laki }\end{array}$ & Perempuan & $\begin{array}{c}\text { Laki- } \\
\text { laki }\end{array}$ & Perempuan & \\
\hline OT & 52 & 48 & 54 & 55 & 56 & 58 & 323 \\
& $(86,7)$ & $(80,0)$ & $(90,0)$ & $(91,7$ & $(93,3)$ & $(96,7)$ & $(89,7)$ \\
\hline CM & 1 & 3 & 2 & 0 & 0 & 0 & 6 \\
& $(1,7)$ & $(5,0)$ & $(3,3)$ & $(0)$ & $(0)$ & $(0)$ & $(1,7)$ \\
\hline Mamak & 7 & 9 & 4 & 5 & 4 & 2 & 31 \\
& $(11,6)$ & $(15,0)$ & $(6,7)$ & $(8,3)$ & $(6,7)$ & $(3,3)$ & $(8,6)$ \\
\hline Total & 60 & 60 & 60 & 60 & 60 & 60 & 360 \\
& $(100)$ & $(100)$ & $(100)$ & $(100)$ & $(100)$ & $(100)$ & $(100)$ \\
\hline
\end{tabular}

Meskipun ada tiga macam golongan orang yang ikut menentukan jumlah uang hilang, namun keputusan akhir tetap berada di tangan orang tua. Orang tua dalam hal lebih mempunyai wewenang dalam penentuan uang hilang. Dari ketiga golongan tersebut orang tua menduduki peringkat teratas yakni sebesar 89,7 persen. Kemudian baru diikuti oleh mamak dan calon pengantin yang masing-masingnya 8,6 persen dan 1,7 persen.

Keterlibatan calon mempelai laki-laki dalam proses penentuan ini dengan alasan turut membatu pihak perempuan untuk meringan biaya yang harus dikeluarkan sebagai persyaratan dalam perkawinan bajapuik $^{10}$. Bantuan itu dapat berbentuk materi dan non materi. Bantuan dalam bentuk materi adalah memberi sebagian atau keseluruhan dari uang hilang yang diminta oleh pihak keluarganya sebagai persyaratan dalam perkawinan bajapuik. Sedangkan bantuan dalam bentuk non materi adalah memberikan masukan atau pertimbangan kepada pihak keluarganya, agar uang hilang yang diminta tidak melebihi kemampuan pihak perempuan.

${ }^{10}$ Keterlibatan lebih jauh dapat dilihat pada bab VIII, terutama pada sub bab yang membicarakan tentang pola-pola tersebunyi dalam perkawinan bajapuik. 
Sementara itu untuk pemberian uang hilang, ada tiga kemungkinan pilihan waktu yang dapat dilakukan oleh pihak perempuan. Pertama, uang hilang dapat diberikan 1-6 bulan sebelum akad nikah dilakukan. Artinya jauh hari sebelum pernikahan berlangsung, uang hilang sudah dapat diberikan kepada pihak laki-laki. Pemberian uang hilang yang lebih awal ini, biasanya atas permintaan dari pihak laki-laki dengan tujuan untuk mempersiapkan segala sesuatunya yang berkaitan dengan pelaksaanaan pernikahan nantinya. Meskipun ini jarang terjadi, namun uang hilang itu biasanya digunakan untuk berbenah diri bagi pihak keluarga laki-laki seperti memperbaiki rumah agar pada saat pesta berlangsung lebih kelihatan bersih dan terawat.

Kedua, uang hilang dapat diberikan pada saat akad nikah dilangsungkan, yakni pada saat calon mempelai laki-laki dijemput ke rumah orang tuanya untuk dinikahkan. Pada saat ini, pemberian uang hilang umum dilakukan dan juga seiring dengan uang jemputan dan persyaratan adat lain. Pemberian uang hilang pada saat ini, selain kelihatannya lebih sakral, juga dirasakan lebih efektif dan efisien.

Ketiga, pemberian uang hilang diberikan setelah pesta pernikahan. Pemberian uang hilang pada waktu ini jarang terjadi, dan biasanya atas permintaan dari pihak perempuan. Kondisi ini terpaksa dilakukan disebabkan oleh kondisi yang sangat terdesak dan tidak ada pilihan lain bagi pihak keluarga perempuan untuk memenuhi uang hilang. Karena pada saat akad nikah berlangsung pihak perempuan belum sanggup untuk memenuhi uang hilang. Kemampuan ekonomi yang kurang, baik dari orang tua dan keluarga luas lainnya, serta kurangnya sarana ekonomi menyentuh kehidupan masyarakat dan ketakutan masyarakat berhubungan dengan lembaga ekonomi tersebut adalah menyebabkan masyarakat mengambil tindakan itu. Mengenai waktu pemberian uang hilang ini dapat dilihat pada tabel 5 berikut ini.

Tabel 5. Waktu Pemberian Uang Hilang

\begin{tabular}{|c|c|c|c|c|c|c|c|}
\hline \multirow[b]{2}{*}{ Kategori } & \multicolumn{2}{|c|}{ Generasi Muda } & \multicolumn{2}{|c|}{ PeLaku } & \multicolumn{2}{|c|}{ Orang Tua } & \multirow[b]{2}{*}{ Total } \\
\hline & $\begin{array}{l}\text { Laki- } \\
\text { laki }\end{array}$ & Perempuan & $\begin{array}{l}\text { Laki- } \\
\text { laki }\end{array}$ & Perempuan & $\begin{array}{l}\text { Laki- } \\
\text { laki }\end{array}$ & Perempuan & \\
\hline 1-6 bulan & $\begin{array}{c}3 \\
(5,0)\end{array}$ & $\begin{array}{c}2 \\
(3,4)\end{array}$ & $\begin{array}{c}0 \\
(0)\end{array}$ & $\begin{array}{c}3 \\
(5,0)\end{array}$ & $\begin{array}{c}2 \\
(3,4)\end{array}$ & $\begin{array}{c}1 \\
(1,7)\end{array}$ & $\begin{array}{c}11 \\
(3,1)\end{array}$ \\
\hline $\begin{array}{l}\text { Saat Akad } \\
\text { Nikah }\end{array}$ & $\begin{array}{c}56 \\
(93,3)\end{array}$ & $\begin{array}{c}56 \\
(93,3)\end{array}$ & $\begin{array}{c}55 \\
(91,7)\end{array}$ & $\begin{array}{c}55 \\
(91,7)\end{array}$ & $\begin{array}{c}58 \\
(96,7)\end{array}$ & $\begin{array}{c}59 \\
(98,3)\end{array}$ & $\begin{array}{c}339 \\
(94,2)\end{array}$ \\
\hline $\begin{array}{l}\text { Sesudah } \\
\text { Pesta }\end{array}$ & $\begin{array}{c}1 \\
(1,7)\end{array}$ & $\begin{array}{c}2 \\
(3,3)\end{array}$ & $\begin{array}{c}5 \\
(8,3)\end{array}$ & $\begin{array}{c}2 \\
(3,3)\end{array}$ & $\begin{array}{c}0 \\
(0)\end{array}$ & $\begin{array}{c}0 \\
(0)\end{array}$ & $\begin{array}{c}10 \\
(2,7)\end{array}$ \\
\hline Total & $\begin{array}{c}60 \\
(100)\end{array}$ & $\begin{array}{c}60 \\
(100)\end{array}$ & $\begin{array}{c}60 \\
(100)\end{array}$ & $\begin{array}{c}60 \\
(100)\end{array}$ & $\begin{array}{c}60 \\
(100)\end{array}$ & $\begin{array}{c}60 \\
(100)\end{array}$ & $\begin{array}{c}360 \\
(100)\end{array}$ \\
\hline
\end{tabular}

Secara umum, pemberian uang hilang yang lebih disukai oleh masyarakat pada saat akad nikah yakni 94,2 persen. Sedangkan pemberian uang hilang lainnya seperti sebelum dan sesudah pesta dipandang masyarakat mempunyai sisi positif dan negatif Pemberian uang hilang lebih awal dapat membantu pihak keluarga laki-laki terdapat 3,1 persen. Namun dilain pihak, kemungkinan terjadinya kemungkiran dipihak lakilaki besar pula terjadi. Begitu juga dengan pemberian uang hilang setelah akad nikah terdapat 2,7 persen. Pihak perempuan dapat saja menghindari pemberian uang hilang dengan dalih bermacam-macam. Dengan pernikahan yang telah dilaksanakan, berarti calon mempelai laki-laki sudah syah menjadi suami anak perempuannya. 
Untuk menghindari kemungkinan tersebut, sebelum akad nikah dibuat kesepakatan yang dihadiri oleh orang tua dan ninik mamak kedua belah pihak. Apabila terjadi kemungkiran salah satu di antara mereka akan mendapat sanksi adat. Sanksi yang biasa dikenakan kepada yang melangggar adalah mengganti satu kali sampai dua kali lipat kerugian yang yang dialami oleh masing-masing pihak yang dirugikan dan penetapan sanksi itu diutarakan pada saat tukar cincin (pertunangan).

Meskipun terdapat tiga macam waktu pemberian uang hilang dalam perkawinan bajapuik, namun untuk saat ini kecendrungannya pada satu pilihan waktu saja yakni pada saat akan dilangsungkan pernikahan. Kemudahan yang diperoleh masyarakat untuk mendapat peminjaman di bank dan pengetahuan luas mengenai sarana ekonomi ini, berimplikasi pada sikap orang tua pada pilihan waktu pemberian uang hilang dalam perkawinan bajapuik. Pihak keluarga perempuan, jauh hari sebelum pelaksanaan pernikahan dilakukan telah mempersiapkan dana yang semestinya harus dikeluarkan terlebih dahulu, walaupun pada akhirnya nanti adanya partisipasi dari keluarga luas (extended family) yang ikut dalam pelaksanaan perkawinan bajapuik ini. Lebih rinci dari sikap orang tua dalam megantisipasi dana yang seharusnya dikeluarkan dalam perkawinan bajapuik dapat dilihat pada tabel 6 berikut ini.

Tabel 6. Sikap Yang Diambil Orang Tua Terhadap Uang Hilang

\begin{tabular}{|c|c|c|c|c|c|c|c|}
\hline \multirow[b]{2}{*}{ Kategori } & \multicolumn{2}{|c|}{ Generasi Muda } & \multicolumn{2}{|c|}{ PeLaku } & \multicolumn{2}{|c|}{ Orang Tua } & \multirow[b]{2}{*}{ Total } \\
\hline & $\begin{array}{l}\text { Laki- } \\
\text { laki }\end{array}$ & Perempuan & $\begin{array}{l}\text { Laki- } \\
\text { laki }\end{array}$ & Perempuan & $\begin{array}{l}\text { Laki- } \\
\text { laki }\end{array}$ & Perempuan & \\
\hline Meminjam & $\begin{array}{c}49 \\
(81,6)\end{array}$ & $\begin{array}{c}40 \\
(66,7)\end{array}$ & $\begin{array}{c}40 \\
(66,7)\end{array}$ & $\begin{array}{c}48 \\
(80,0)\end{array}$ & $\begin{array}{c}54 \\
(90)\end{array}$ & $\begin{array}{c}52 \\
(86,7)\end{array}$ & $\begin{array}{c}282 \\
(78,3)\end{array}$ \\
\hline $\begin{array}{l}\text { Menangguh- } \\
\text { kan }\end{array}$ & $\begin{array}{c}9 \\
(15,0)\end{array}$ & $\begin{array}{c}11 \\
(18,3)\end{array}$ & $\begin{array}{c}17 \\
(28,3)\end{array}$ & $\begin{array}{c}12 \\
(20,0)\end{array}$ & $\begin{array}{c}6 \\
(10)\end{array}$ & $\begin{array}{c}8 \\
(13,3)\end{array}$ & $\begin{array}{c}63 \\
(17,5)\end{array}$ \\
\hline Membatalkan & $\begin{array}{c}1 \\
(1,7)\end{array}$ & $\begin{array}{c}6 \\
(10,0)\end{array}$ & $\begin{array}{c}2 \\
(3,3\end{array}$ & $\begin{array}{c}0 \\
(0)\end{array}$ & $\begin{array}{c}0 \\
(0)\end{array}$ & $\begin{array}{c}0 \\
(0)\end{array}$ & $\begin{array}{c}10 \\
(2,8)\end{array}$ \\
\hline $\begin{array}{l}\text { Mencari } \\
\text { Calon Lain } \\
\text { keluar }\end{array}$ & $\begin{array}{c}1 \\
(1,7)\end{array}$ & $\begin{array}{c}3 \\
(5,0)\end{array}$ & $\begin{array}{c}1 \\
(1,7)\end{array}$ & $\begin{array}{c}0 \\
(0)\end{array}$ & $\begin{array}{c}0 \\
(0)\end{array}$ & $\begin{array}{c}0 \\
(0)\end{array}$ & $\begin{array}{c}5 \\
(1,4)\end{array}$ \\
\hline Total & $\begin{array}{c}60 \\
(100)\end{array}$ & $\begin{array}{c}60 \\
(100)\end{array}$ & $\begin{array}{c}60 \\
(100)\end{array}$ & $\begin{array}{c}60 \\
(100)\end{array}$ & $\begin{array}{c}60 \\
(100)\end{array}$ & $\begin{array}{c}60 \\
(100)\end{array}$ & $\begin{array}{c}360 \\
(100)\end{array}$ \\
\hline
\end{tabular}

Tabel 14 di atas menunjukan bahwa pada umumnya orang tua lebih cendrung melakukan peminjaman di bank yakni 88,3 persen dan 11,7 persen yang menangguhkan atau mengundur pelaksanaan perkawinan sampai pada perkiraan waktu tertentu, uang itu dapat dipenuhi. Sedangkan untuk membatalkan dan mencari calon lain di luar Pariaman tidak ada dilakukan oleh orang tua. Penangguhan atau pengunduran pelaksanaan perkawinan itu secara umum dirasakan oleh orang tua yang tidak mempunyai saudara atau jikapun ada, tetapi kemampuan ekonominya relatif rendah, sehingga tidak dapat diharapkan secara materi untuk menutupi jumlah uang hilang yang harus dipenuhi.

Untuk pemberian uang hilang ini, aktor yang terlibat adalah keluarga luas (extended family), dari pihak ibu dan tetangga terdekat dibawah satu komando yakni ninik mamak. Pada saat itu, ninik mamak kedua belah pihak berperan dalam rangka memberi dan menerima uang hilang, disamping yang lain turut menyaksikan dan sekaligus mensyahkan persyaratan yang telah ditetapkan. 


\section{Sejarah Munculnya Uang Hilang}

Sejarah munculnya uang hilang sampai saat ini, merupakan suatu rangkain cerita dari mulut ke mulut. Walaupun lukisan cerita itu sangat terang dan mudah dipahami, namun sangat susah dijadikan sebagai tonggak sejarah dan masih diragukan kebenarannya mengenai munculnya uang hilang. Makin jauh, menyelami pendapat masyarakat, maka semakin banyak diperoleh informasi tentang penyebab munculnya uang hilang. Adapun penyebab munculnya uang hilang dalam perkawinan bajapuik antara lain:

Pertama, uang hilang muncul sebagai kompensasi atau imbalan sesuatu masalah. Dimana adanya suatu keluarga yang mempunyai anak gadis yang telah "rusak" (tidak gadis lagi). Masalah ini sudah menjadi rahasia umum, dimana untuk mencarikan jodoh bagi anak gadis tersebut tentu saja akan mengalami kesulitan. Kondisi anak gadis seperti ini dianggap hina dan tidak ada laki-laki yang mau untuk mempersuntingnya. Jalan keluar yang ditempuh oleh orang tuanya adalah mencarikan seorang laki-laki yang mau mempersunting anaknya tersebut. Sebagai imbalan dari kesedian dari laki-laki itu diberilah uang oleh pihak keluarga yang perempuan. Uang inilah yang semula disebut dengan uang hilang.

Kedua, sebagai balas jasa langsung. Bagi orang tua, tentu mempunyai harapan kepada anaknya nanti setelah dewasa. Untuk itu anaknya disekolahkan mulai dari SD sampai ke Perguruan Tinggi, dengan maksud setelah menamatkan pendidikan itu akan mendapatkan pekerjaan yang lebih baik. Apakah akan menjadi pegawai negeri, pegawai swasta ataupun berwiraswasta. Orang tua mengharapkan penghasilan sianak itu nanti dapat membantu kehidupannya kelak dan juga dapat membantu menyekolahkan adik-adiknya. Untuk mendukung keberhasilan si anak, orang tua tidak segan-segan untuk mengorbankan apa saja untuk biaya sekolahnya. Tapi baru saja anak mulai berkerja atau diujung pendidikannya, sudah ada saja keluarga yang mempunyai anak gadis untuk meminangnya atau meminta sianak untuk dijadikan menantu. Pada kondisi ini, orang tua dihadapkan kepada dua pilihan. Di satu sisi orang tua menyadari, bahwa sudah menjadi kodratnya manusia di mana seorang gadis apabila telah menginjak dewasa tentu akan bersuami dan jejaka akan beristeri. Namun di sisi yang lain, jika anak sudah mempunyai isteri sudah pasti akan mempunyai tanggungjawab kepada keluarganya (anak dan isteri). Bantuan kepada orang tua dan adik-adiknya sudah barang tentu akan berkurang bahkan tidak ada sama sekali. Sering terjadi, apabila anak sudah beristeri, sianak lupa akan kewajibanya kepada orang tua dan adik-adiknya. Inilah yang mencemaskan bagi sebagian orang tua di Pariaman. Dari sini muncul hasrat orang tua untuk meminta uang hilang sebagai balas jasa selama membesarkan sianak mulai dari kecil hingga menjadi orang. Apalagi jika si anak itu baik sikapnya dan mempunyai kedudukan yang baik pula, banyak orang tua yang mempunyai anak gadis untuk meminangnya dan dijadikan menantu. Maka disinilah berlaku prinsip ekonomi, kalau permintaan banyak, maka harga akan tinggi dan bila permintaan sedikit, maka harga menjadi rendah. Atas dasar inilah uang hilang menjadi berjuta-juta.

Ketiga, karena kekayaan yang dimiliki oleh pihak perempuan, atau dengan istilah "dek ameh kameh, dek padi menjadi", artinya dengan uang bisa didapatkan apa saja, termasuk untuk mendapatkan menantu. Suatu keluarga yang mempunyai anak gadis 
dan mampu secara ekonomi, sudah barang tentu berkeinginan untuk mendapatkan menantu yang terpandang seperti kedudukan, pendidikan yang tinggi dan pekerjaan yang tetap atau pedagang besar dll, walaupun anak gadisnya tidak cantik dan berpendidikan tinggi. Dengan uang atau kemampuan ekonomi yang dimilikinya dapat menawarkan uang yang cukup banyak kepada pria yang dituju asalkan mau diterima menjadi menantu. Uang inilah yang disebut dengan uang hilang.

Keempat, kebanggaan atau pamer moral. Kedua keluarga, baik dari pihak laki-laki maupun dari pihak perempuan sama-sama mempunyai kemampuan dalam bidang ekonomi. Untuk menunjuk kepada masyarakat banyak, maka keluarga itu memberi uang hilang.

Kelima, latah atau Ikut-ikutan. Oleh karena banyak masyarakat yang melaksanakan uang hilang, baik oleh karena mengharapkan balas jasa, pamer moral dan lain-lain maka hampir semua masyarakat dalam daerah Kabupaten Padang Pariaman dan Kota Pariaman melaksanakan uang hilang dalam rangkain acara perkawinan.

Dari kelima penyebab di atas tidak satupun yang menyertai dengan tahun munculnya uang hilang, sehingga itu berimplikasi pada sulitnya menentukan tongggak sejarah munculnya uang hilang itu sendiri. Namun demikian, dari sejarah tentang Pariaman tempo dulu yang di tulis oleh Zakaria (1932) ${ }^{11}$, diperoleh informasi bahwa penyebab muncul uang hilang, lebih besar di sebabkan oleh pengaruh ekonomi (zaman melaise). Krisis ekonomi yang menyebabkan sulitnya lapangan pekerjaaan menyebabkan orang yang mempunyai kedudukan pada saat itu diberi uang hilang. Pada masa itu, orang yang yang bergelar seperti Sidi, Bagindo dan Sutan di jemput dengan sesukanya oleh orang yang datang. Sedangkan bagi laki-laki yang mempunyai usaha sendiri seperti berniaga atau guru agama besarnya uang hilangnya sekurang-kurangnya f 30 sampai f 300. Kemudian uang hilang ini akan semangkin bertambah jumlahnya, apabila seorang laki-laki tersebut mempunyai pangkat yang tinggi dan mempunyai gaji yang besar. Intinya munculnya uang hilang disebabkan oleh keinginan untuk mendapatkan menantu yang lebih baik, dengan kedudukan dan pekerjaan yang tetap. Ini sekaligus mengisyaratkan bahwa uang hilang sudah ada semejak tahun 1932 tersebut.

\section{UANG TUNGKATAN}

\section{Konsep Uang Tungkatan}

Selain uang di atas, uang yang lain yang dikenal dalam perkawinan bajapuik adalah uang tungkatan. Uang tungkatan adalah uang tembusan dari benda-benda tungkatan yang dibawa oleh pihak perempuan sebagai persyaratan untuk menjemput mempelai laki-laki untuk dinikahkan. Benda-benda tungkatan dalam perkawinan bajapuik berupa tiga bentuk cincin yang dikat kain kuning. Banyaknya cincin dan tungkatan itu bergantung pada tinggi rendahnya martabat kaum tersebut. Kalau orang

\footnotetext{
${ }^{11}$ Di tulis ulang oleh Anas Navis (1992) dalam salin naskah tentang Riwayat Kota Pariaman. Namun sebutan untuk uang hilang, disebut dengan uang jemputan. Jika kembali kepada konsep awal dari uang jemputan dan uang hilang mempunyai perbedaan. Uang jemputan berupa benda-benda ekonomis; seperti emas, kendaraan atau rumah dan uang hilang berupa uang. Atas dasar itu penyebutan untuk uang jemputan di atas dianggap keliru dan yang benarnya adalah uang hilang. Sehingga dapatlahlah dikatakan yang dimaksudnya oleh pengarang adalah uang hilang.
} 
keturunan bangsawan tungkatan lima sampai tujuh bentuk cincin, Tetapi kalau orang biasa, jumlah tungkatannya satu atau tiga cincin (Zakaria, dalam Navis 1992).

Benda-benda tungkatan yang dibawa oleh pihak perempuan biasanya dilengkapi pula dengan; tongkat, pedang, payung, sewah (pisau) dan buah tangan. Buah tangan disebut juga kampia sirih. Kampia sirih dilengkap ini adalah berupa, daun sirih, gambir, pinang, tembakau dan sadah (kapur). Kampia sirih ini merupakan ketentuan adat yang harus dipenuhi karena setiap perkawinan di Minangkabau.

Semua syarat-syarat ini dibawa pada saat menjemput marapulai untuk melakukan pernikahkan. Benda-benda tungkatan itu tidak menjadi hak milik pihak laki-laki tetapi kembali lagi kepada pihak perempuan. Agar benda-benda tungkatan itu dapat kembali kepada pihak perempuan, maka pihak perempuan harus menembusnya dengan sejumlah uang. Uang inilah yang disebut dengan uang tungkatan atau disebut dengan uang tembusan tungkatan. Jumlah uang tungkatan itu tidak banyak, berkisar antara Rp 150.000-200.000. Dengan jumlah tersebut, maka dapat dipastikan wujud dari uang tungkatan adalah uang.

\section{Makna dan Kegunaan Uang Tungkatan}

Tungkatan adalah berupa benda-benda. Semua benda-benda yang termasuk ke dalam tungkatan tesebut mempunyai makna. Dalam perkawinan bajapuik benda-benda tungkatan pada awalnya merupakan simbolisasi dari status atau kedudukan dan asalusul seorang laki-laki yang akan diterima sebagai menantu, apakah berasal dari golongan biasa, penghulu atau golongan bangsawan. Atas dasar itu, jumlah tungkatan dalam perkawinan bjapuik, ada tungkatan tiga, lima dan tujuh. Tungkatan tiga terdiri dari tiga macam cincin yakni emas, suaso dan perak, atau yang disebut dengan cincin tigo bantuak (tiga bentuk) adalah untuk laki-laki yang mempunyai gelar keturunan. Tungkatan lima terdiri dari; tiga macam cincin dilengkapi dengan sewah dan payung adalah untuk laki-laki yang mempunyai gelar keturunan dan memangku jabatan sebagai penghulu dan keturunannya. Terakhir tungkatan tujuh, selain tiga macam cincin dilengkapi dengan sewah, payung, pedang dan tongkat adalah untuk laki-laki yang mempunyai gelar keturunan dan jabatannya sebagai raja dan keturunannya.

Meskipun saat ini, penghormatan atau penghargaan kepada seorang laki-laki yang akan diterima sebagai menantu terletak pada status sosial yang mengacu pada prestasi, namun benda tungkatan ini masih tetap berlaku dalam perkawinan bajapuik. Pada umumnya jumlah tungkatan yang dibawa tungkatan tiga saja. Sementara untuk tungkatan lima dan tujuh hampir tidak ada dalam pelaksanaannya. Benda tungkatan yang ada dalam perkawinan bajapuik, merupakan sebagai simbolisasi dari asal-usul dari seorang laki-laki yang mempunyai gelar keturunan.

Semua benda-benda tungkatan mempunyai makna dan kegunaan. Secara umum makna dan kegunaan benda-benda itu sebagai persiapan bagi mempelai laki-laki ditengah jalan nantinya ${ }^{12}$. Tongkat berguna sebagai penunjuk jalan; pedang dan

\footnotetext{
${ }^{12}$ Karena pernikahan pada saat itu dilakukan pada malam hari. Oleh sebab itu perlengkapanperlengkapan itu sebagai senjata bagi mempelai laki-laki pada saat menunju ke rumah mempelai perempuan, jika pada suatu saat dihadang oleh musuh ditengah jalan.
} 
sewah sebagai senjata untuk melindungi diri dari serangan musuh di tengah jalan dan payung digunakan untuk melindungi diri dari hujan, jika dalam perjalan turun hujan.

Begitu juga dengan buah tangan yang berupa kampia siriah yang dibawa mempunyai makna pula dalam perkawinan bajapuik. Kampia siriah yang berisi salapah ini dapat dijadikan simbol atau lambang untuk mengetahui perawan atau tidaknya penganten perempuan. Oleh sebab itu yang menerima kampia sirih dan salapah adalah kapalo mudo. Orang mudo inilah yang akan menerima dan menilai barang bawaan itu. Biasanya dalam penerimaan barang bawaan itu, kapalo mudo memeriksa satu persatu dan disaksikan keluarga kedua belah pihak. Jika terjadi suatu keganjilan, maka wewenang kapalo mudo untuk menyampaikan kepada ninik mamak dari calon pengantin laki-laki dan untuk diteruskan kepada ninik mamak dari calon pengantin perempuan. Untuk selanjutnya ninik mamak inilah yang akan membuat perhitungan atau konsensus baru. Dengan simbol salapah ini, perkawinan bisa menjadi batal atau dibuat perhitungan baru lagi mengenai uang hilang. Tetapi ada kecenderungan uang hilang yang dinaikan antara 50\% sampai dengan $100 \%$.

Dengan demikian dapatlah dipahami, bahwa alat-alat atau benda-benda yang tergabung dalam tungkatan tersebut menunjukan; 1) sebagai simbol status dan asal usul seseorang, dan 2) sebagai sarana untuk melihat keperawanan seorang mempelai perempuan.

Kemudian uang tungkatan yang diberikan itu dapat dipahami sebagai uang lelah atau belaian kepada ketua marapulai atau kapalo mudo. Dimana ketua marapulai telah meluangkan waktunya untuk mendampingi mempelai laki-laki pada saat melangsungkan pernikahan. Uang tungkatan itu bergunakan untuk membeli rokok atau minuman bagi ketua marapulai dan anggotanya.

\section{Waktu Penentuan dan Pemberian Uang Tungkatan}

Berbeda halnya dengan uang jemputan dan uang hilang, uang tungkatan ditentukan setelah pernikahan dilangsungkan dan berkaitan dengan benda-benda tungkatan. Artinya mempelai laki-laki dijemput untuk melakukan pernikahan, pihak perempuan membawa benda-benda tungkatan dan diberikan kepada pihak keluarga laki-laki sebagai persyaratan dalam perkawinan bajapuik. Benda-benda tungkatan itu tidak menjadi hak milik dari pihak laki-laki dan dibawa kembali pulang ke rumah pihak perempuan. Permintaan kembali benda-benda tungkatan oleh pihak perempuan, maka saat itu penentuan uang tungkatan oleh ketua marapulai.

Setelah ada penentuan mengenai jumlahnya, uang tungkatan diberikan oleh pihak perempuan yang diwakili oleh ninik mamak kepada ketua marapulai dari pihak lakilaki. Uang tungkatan diberikan saat marapulai dan rombongan hendak pulang ke rumah orang tuanya setelah pernikahan dilakukan.

\section{Sejarah Munculnya Uang Tungkatan}

Tidak banyak informasi yang diperoleh tentang kapan munculnya uang tungkatan dalam perkawinan bajapuik. Berdasarkan informasi dan kajian sejarah tentang perkawinan bajapuik tempo dulu, maka ada dua versi sebagai berikut.

Versi pertama, munculnya uang tungkatan seiring dengan adanya perkawinan bajapuik. Artinya uang tungkatan telah ada, ketika perkawinan bajapuik itu ada di 
dalam masyarakat Pariaman. Ini menunjukan uang tungkatan telah ada semenjak dahulunya.

Versi kedua, uang tungkatan tidak pernah disebutkan dalam perkawinan bajapuik, namun yang ada adalah benda-benda tungkatan itu sendiri. Dari kedua versi ini, kiranya versi kedua yang lebih mendekati kebenaran. Pendapat itu didukung oleh kajian sejarah tentang perkawinan Pariaman tempo dulu yang dibuat oleh Said Zakaria (1932), yang ditulis ulang oleh Anas Navis (1992). Uang tungkatan tidak ada dalam perkawinan bajapuik dan yang ada itu adalah benda-benda dari tungkatan itu sendiri. Artinya uang tungkatan ada dalam perkawinan bajapuik muncul belakangan dan belum ada ketika adanya perkawinan bajapuik. Ungkapan ini sekaligus membuktikan bahwa uang tungkatan tidak ada dalam perkawinan bajapuik pada waktu itu. Bahkan pada saat itu biaya perkawinan adalah tanggungjawab masyarakat. Kemudian terjadinya krisis ekonomi pada tahun 1929 yang terkenal dengan zaman melaise, yang menyebabkan kehidupan ekonomi masyarakat morat-marit yang disebabkan oleh mata pencarian susah didapatkan. Sementara itu pihak perempuan dalam penyelenggaran pesta mempunyai ekonomi yang cukup untuk itu. Namun untuk pelaksanaan pesta tidak dapat dilaksanakan sendiri terutama menyangkut masalah adat dan sudah dapat dipastikan melibatkan anggota masyarakat yang paham mengenai adat-istiadat tersebut. Oleh sebab itu sebagai imbalan dari anggota masyarakat yang turut menyukseskan pelaksanaan perkawin itu, diberilah sejumlah uang sebagai pengganti waktu yang terpakai dalam pelaksanaan perkawinan itu. Dengan demikian uang tungkatan dimaksud sebagai wujud perhatian dari yang punya hajat kepada anggota masyarakat yang tergolong kepada ninik mamak dan kepalo mudo, atas jasa yang diberikan demi terlaksananya perkawinan bajapuik.

\section{UANG SELO}

\section{Konsep Uang Selo}

Uang selo merupakan salah satu bentuk dari berbagai macam uang yang harus dikeluarkan oleh pihak keluarga perempuan dalam perkawinan bajapuik. Uang Selo diberikan oleh pihak perempuan kepada ninik mamak dari pihak laki-laki yang hadir pada saat pertunangan (tukar cincin). Oleh sebab itu uang selo ini disebut juga dengan uang ninik mamak.

Pada umumnya uang selo tidak mempunyai standar yang tetap. Oleh sebab itu ada kecendrungan jumlah berubah-berubah sesuai permintaan ninik mamak dari pihak laki-laki. Permintaan besar kecilnya uang selo, selain didasarkan pada oleh banyaknya jumlah ninik mamak yang datang menghadiri, juga dengan melihat kondisi ekonomi orang yang datang (pihak perempuan). Memperhatikan pada kondisi tersebut, sebagian nagari membuat Perna (Peraturan Nagari) tentang uang selo, agar lebih tertip dan tidak berlebihan. Peraturan itu pertama kali dibuat oleh Kenagarian Pilubang Kecamatan Sungai Limau, karena gagasan itu dianggap baik, maka hampir separoh dari jumlah kenagarian yang ada di lingkungan Kabupaten Padang Pariaman menerapkan Perna tersebut di dalam nagarinya. Sementara itu nagari-nagari yang tidak mempunyai Perna (Peraturan Nagari) mengenai uang selo, jumlah uang selo ditetapkan berdasarkan kesepakatan dari keluarga kedua belah pihak. 
Penetapan besar-kecil jumlah uang selo dalam suatu nagari didasar atas kondisi perekonomian masyarakatnya dan jangan sampai memberatkan pihak perempuan. Jumlah uang selo yang berlaku sekarang berkisar antara Rp 200.000 sampai Rp 700.000 (1 emas). Meskipun sudah ada penetapan itu, namun dalam realitanya dilapangan masih terdapat jumlah uang selo sampai 1 juta. Ini merupakan jumlah yang relatif besar untuk ukuran uang selo. Tetapi untuk sebagian masyarakat tidak menjadi persoalan, karena uang itu akan dibagi-bagi pula untuk sejumlah orang/ninik mamak yang datang pada acara tersebut, sehingga masing-masing dapat bagian antara Rp 50.000 sampai Rp 100.000. Pembagian itu didasarkan pula pada kedududuknya pada acara tersebut.

Pada dasarnya, keberadaan uang selo ini dalam perkawinan bajapuik, tidak menjadi beban, seperti uang hilang yang dirasakan oleh sebagian masyarakat saat ini. Ketika uang selo di minta oleh pihak keluarga laki-laki sebagai sebuah persyaratan yang harus dipenuhi, biasanya pihak keluarga perempuan menerima dan memenuhi permintaan uang selo ini. Jarang sekali terjadi penawaran dalam penetapan jumlah uang selo dari pihak perempuan, karena jumlah yang relatif kecil dan masih terjangkau oleh segenap lapisan masyarakat.

\section{Tujuan dan Kegunaan Uang Selo}

Uang selo diberikan kepada ninik mamak bertujuan sebagai wujud perhatian kepada ninik mamak yang telah meluangkan waktunya dalam pelaksanaan pertunangan. Mereka telah meninggalkan pekerjaan untuk beberapa saat dan bahkan kadangkadang sampai satu hari, sehingga pada hari itu mereka tidak mempunyai penghasilan yang akan memenuhi kebutuhan hidupnya. Sebagai pengganti waktunya untuk berusaha itu, maka diberilah uang selo.

Uang selo hanya diberikan kepada ninik mamak pihak laki-laki dan tidak kepada ninik mamak dari pihak perempuan. Pertimbangan karena sesuai dengan adat Minangkabau yang berlaku umum dan tidak terkecuali di Pariaman, bahwa dalam adat perkawinan, pihak perempuan adalah orang yang datang. Sebagai orang datang dipahami, sebagai orang yang mempunyai kepentingan ${ }^{13}$ dalam perkawinan ini. Jadi tidak salahnya juga orang yang mempunyai kepentingan untuk berkorban dalam hal ini. Oleh sebab itu sewajarnyalah pihak perempuan memberi uang selo kepada ninik mamak untuk pihak laki-laki. Tanpa kehadirannya pada acara tersebut, pertunangan tidak berjalan sebagaimana mesti. Peran ninik mamak dalam hal ini adalah orang yang mengetahui tentang adat istiadat.

Uang selo ini diberikan kepada salah seorang dari ninik mamak pihak pengantin laki-laki yang dianggap dituakan dan sekaligus untuk pembagiannya diserahkan kepadanya. Karena semua ninik mamak yang ikut menghadiri acara tersebut akan mendapat bagian. Tetapi jumlah yang diterima oleh ninik mamak-ninik mamak itu tidak sama. Pembagian itu di dasarkan kepada peran serta dan kedudukannya di dalam masyarakat. Kegunaan uang selo bagi ninik mamak ini biasanya adalah untuk membeli rokok dan minuman atau memenuhi kebutuhan rumah tangga lainnya.

\footnotetext{
${ }^{13}$ Untuk menikahkan anak perempuannya, karena dalam adat Minangkabau perempuan yang telah cukup umur menjadi beban keluarga dan kaum. Oleh sebab itu tidak salahnya juga pihak perempuan berkorban materi, untuk mendapatkan keuntungan yang lebih besar yakni menantu.
} 
Alasan ini dapat diterima akal, karena seharian, waktunya dihabiskan untuk menghadiri salah satu dari prosesi perkawinan. Apalagi kehidupan di desa pada umumnya di bidang pertanian. Artinya dalam hal ini, jika mereka tidak berusaha dengan tenaganya maka mereka tidak akan mendapat uang. Sementara mereka harus menghidupi anak dan keluarganya juga. Jadi wajar saja mereka mendapatkan uang ini dan di gunakan untuk kebutuhan hidupnya sehari-hari.

\section{Waktu Penentuan dan Pemberian Uang Selo}

Jauh hari sebelum tukar cincin, uang selo sudah di bicarakan antara kedua belah pihak. Tepatnya pada tata cara meresek telah dibuat kerangkanya mengenai bentuk bentuk uang yang harus disediakan oleh pihak perempuan. Ketika waktu tiba, pihak perempuan hanya menjalankan sesuai dengan kesepakatan yang telah dibuat sebelumnya. Penentuan uang selo biasanya dilakukan di rumah pihak laki-laki, karena dalam adat perkawinan yang berlaku umum pihak perempuan yang datang ke rumah calon pengantin laki-laki. Oleh sebab itu, pembicaraan mengenai uang selo ini dilakukan di rumah calon penganten laki-laki.

Kehadiran pihak perempuan ke rumah pihak calon pengantin laki-laki pada saat itu, selain orang tua dan saudara yang terdekat, didampingi pula oleh salah seorang ninik mamak. Begitu juga sebaliknya dari pihak laki-laki telah menunggu pula orang yang sama. Pada pertemuan antar keluarga inilah uang selo dibicarakan. Dalam pertemuan itu juga dibicarakan hal-hal lain yang menyangkut persyaratan yang harus di penuhi oleh pihak perempuan seperti uang jemputan dan uang hilang dan uang tungkatan. Keputusan mengenai jumlah uang selo dikemukakan oleh ninik mamak dari pihak laki-laki.

Uang selo yang telah ditetapkan itu, diberikan pada saat tukar cincin atau pertunangan. Pemberian itu dilakukan oleh ninik mamak dari pihak perempuan kepada ninik mamak pihak penganten laki-laki. Penyerahan berlangsung di rumah calon pengantin laki-laki yang dihadiri oleh oleh ninik mamak, orang tua serta kerabat dari calon pengantin laki-laki.

\section{Sejarah Munculnya Uang Selo}

Informasi tentang muncul uang selo dalam perkawinan bajapuik tidak banyak diketahui, karena tidak ada bukti-bukti tertulis yang dapat menjelaskannya. Meskipun demikian dari pengalaman (life histori) dari pelaku perkawinan yang tergolong berumur lanjut, yang usianya antara 69 sampai 80 tahun tahun, tidak semuanya melaksanakan uang selo dalam perkawinan. Ada 4 orang diantaranya yang melaksana uang selo dalam perkawinannya dengan usia perkawinannya antara 30-45 tahun. Dengan demikian dapat dipahami, bahwa munculnya uang selo belakangan dan tidak ada semenjak perkawinan bajapuik ada. Sebagai gambaran dapat dilihat pada tabel 7 berikut ini. 
Tabel 15. Perkiraan Muncul Uang Selo

\begin{tabular}{|l|l|c|c|c|}
\hline No & Kode Informan & Umur & Tahun Menikah & Pakai Uang selo \\
\hline 1 & A G & 70 & 1964 & - \\
\hline 2 & F & 69 & 1962 & - \\
\hline 3 & S M & 72 & 1962 & - \\
\hline 4 & I M & 80 & 1954 & $\sqrt{ }$ \\
\hline 5 & S & 74 & 1965 & - \\
\hline 6 & M L & 80 & 1960 & - \\
\hline 7 & A Z & 65 & 1970 & - \\
\hline 8 & B & 73 & 1958 & $\sqrt{ }$ \\
\hline 9 & B & 73 & 1960 & - \\
\hline 10 & T M & 66 & 1968 & - \\
\hline 11 & U A & 80 & 1953 & - \\
\hline 12 & M R & 75 & 1960 & - \\
\hline 13 & M & 70 & 1963 & 1955 \\
\hline 14 & A & 78 & & \\
\hline
\end{tabular}

Kemudian prakteknya uang selo lebih marak dilakukan sekitar tahun 1970-an. Penyebab munculnya uang selo lebih dikarenakan oleh semakin berkurangnya kadar sosial masyarakat.

\section{KESIMPULAN}

Ada empat macam bentuk-bentuk uang yang dipertukaran dalam perkawinan bajapuik.

1. Uang jemputan adalah uang yang diberikan oleh pihak perempuan kepada pihak laki-laki sebagai persyaratan dalam perkawinan dan dikembalikan lagi pada saat mengunjungi mertu untuk pertama kalinya. Uang jemputan ini berwujud benda yang bernilai ekonomis seperti emas dan benda lainya. Pada awalnya uang jemputan mempunyai makna sebagai penghormatan kepada calon mempelai laki-laki yang diterima sebagai menantu dan saat ini bermakna sebagai pemberian orang tua kepada anak perempuan atau menantunya. Penentuan uang jemputan dilakukan pada acara meresek dan bersamaan dengan penentuan persyaratan lainnya. Sedangkan untuk pemberian dilakukan pada saat menjemput calon mempelai laki-laki untuk melaksanakan pernikahan di rumah kediaman pihak perempuan

2. Uang hilang adalah uang yang diberikan oleh pihak perempuan kepada pihak laki-laki sebagai persyaratan dalam perkawinan dan dapat dipergunakan sepenuhnya oleh pihak laki-laki, terutama orang tua. Uang hilang berwujud benda, khususnya berupa uang. Uang hilang bermakna sebagai penghargaan terhadap prestasi yang dimiliki oleh calon mempelai laki-laki. Penentuan dan pemberian uang hilang seiring dengan uang jemputan, yakni pada saat meresek dan pada saat pernikahan dilangsungkan.

3. Uang tungkatan adalah uang tembusan dari benda-benda tungkatan yang dibawa oleh pihak perempuan sebagai persyaratan untuk menjemput mempelai laki-laki untuk dinikahkan. Uang tungkatan bermakna sebagai belaian terhadap kepalo mudo yang telah bersedia hadir dan mengikuti 
proses pernikahan yang dilakukan. Sebagai balas jasanya diberi uang tungkatan. Penentuan dan pemberian uang tungkatan dilakukan setelah pernikahan dilangsungkan dan calon mempelai laki-laki dan rombongan hendak pulang kerumah orang tua.

4. Uang selo adalah uang yang harus dikeluarkan oleh pihak perempuan dalam perkawinan bajapuik dan diberikan kepada ninik mamak yang hadir pada saat pertunangan (tukar cincin). Uang selo mempunyai makna sebagai belaian kepada ninik mamak yang telah bersedia hadir pada saat tukar cincin. Penentuan uang selo dilakukan pada saat meresek dan pemberiannya dilakukan pada saat tukar cincicin.

5. Faktor- faktor penyebab munculnya macam-macam uang dalam perkawinan bajapuik, pada umumnya akibat pengaruh ekonomi.

Hasil penelitian di atas menunjukkan terdapat berbagai macam pertukaran dalam perkawinan bajapuik. Secara umum menunjukan pertukaran tersebut lebih berorientasi pada banyaknya uang yang harus disediakan oleh pihak keluarga perempuan. Padahal menurut Skidmore (1979), pertukaran sosial tidak selalu dapat diukur dengan uang, sebab dalam transaksi sosial juga dipertukarkan yang nyata dan tidak nyata. Adanya berbagai macam pertukaran itu dimaksudkan untuk menghindari sesuatu seperti penderitaan, keadaan yang memalukan lainnya. Untuk itu pertukaran dilakukan dalam rangka untuk mendapatkan keuntungan yang lebih besar yakni menantu atau suami bagi anak perempuannya. Berdasarkan atas nilainilai yang terkandung pada bentuk-bentuk pertukaran tersebut, maka perkawinan bajapuik dapat exis hingga saat ini.

\section{Saran}

Pemahaman nilai-nilai adat menjadi syarat penting bagi keberadaan identitas suku bangsa. Jika itu terabaikan dapat mengakibat hilangnya suatu identitas. Oleh sebab KAN (Kerapatan Adat Nagari) dan LKAAM (Lembaga Kerapatan Alam Adat Minangkabau) sebagai lembaga yang berkepentingan dalam hal ini perlu diaktifkan perannya, melalui pengambil kebijakan (pemerintah) yang mempunyai tekat yang kuat untuk turut memperhatikan kedua lembaga ini.

\section{DAFTAR PUSTAKA}

Anderson, J.H. 1995. Rhetorical Objectivity in Malinowsk's Argonauts, dalam Brown (Editor), Postmodern Representations; Truth, Power and Mimesis in the Human Science and Public Culture. University of Illinois Press: Chicago.

Creswell, J.W. 1995. Research Design:Qualitative dan Quantitative Aproaches. Sage Publications: London.

Guba dan Lincoln. 2000. Paradigmatic Controversies, Contradiction, and Emerging Confluences. Dalam Norman K.Denzin dan Yvonna S.Lincoln. Handbook of Qualitative Research. Secon Edition. Sage Publications. Inc

Howe, KR. 2004. A Critique of Experimentalism. In: Qualitative Inquiry Vol.10 No.1. 
Lamanna, Ann Mary and Agnes Riedmann. 1987. Marriages And Famillies: Making Choices Throughout The Life Cycle. Wadswortth Publishing Company: Belmont California.

Navis, 1984. Alam Terkembang Menjadi Guru. Grafiti: Jakarta.

Poloma, M. Margaret. 2000. Sosiologi Kontemporer. Rajawali Press: Jakarta.

Putra, H.S.A. 2003. Ekonomi Moral, Rasional dan Politik dalam Industri kecil di Jawa; Essai-essai Antropologi Ekonomi. Kepel Press: Yogyakarta.

Ritzer, George. 1985. Sosiologi Ilmu Berparadigma Ganda. Rajawali Press: Jakarta.

Salim, Agus (Penyunting). 2001. Teori dan Paradigma Penelitian Sosial. Penerbit PT Tiara Wacana: Yogyakarta.

Skidmore, W. 1979. Theorotical Thinking in Sociology (Second Edition). Cambridge Universiy Press: New York.

Sukmasari, Fiony.1983. “Perkawinan Adat Minangkabau”. Karya Indah: Jakarta.

Turner, Jonathan H, 1998. The Structure of Sosiological Theory (Sixth Edition), Wadsworth Publishing Company: USA. 